\title{
Cambridge Economics: A place, a people, an academic community and its Palgrave Companion
}

Cord, Robert A. (editor), 2017, The Palgrave Companion to Cambridge Economics, London: Palgrave Macmillan, 2 Vol., pp. XVII, 1225. f 165 (Hardcover) ISBN 978-1-137-41233-1

The Palgrave Companion's two volume set on Cambridge Economics is part of an ongoing project by Robert Cord to bring together contributions that capture Economics, as it was, and is, practised in historically important universities for the subject. This publication project follows Cord's Ph.D. work that discussed research centres in economics in the 1930s, with special reference to Cambridge, Oxford and the LSE (Cord, 2012). In that book Cord analysed the relative success of these research centres by utilising a framework that identified sociological, technical, intellectual and financial factors to explain why some centres where more successful than others. In contradistinction, this edited set starts with a collection of surveys 'from within', with academics reviewing fields of research through narratives that capture specific traditions and/or the interface of economics with related fields/faculties in Cambridge. These form Part I, titled "Themes in Cambridge Economics". Part II, titled "Some Cambridge Economists", has an extensive set of intellectual biographies of the major economists associated with Cambridge, who also figure in the narratives constructed in Part I. All of this yields more than a thousand pages of text, from fifty one academics contributing the various pieces. This is a herculean task, and the very scope of the project and its execution awes the reader. It is commendable that Cord not only completed this task but also amassed contributions from celebrated academics that know intimately Cambridge and its many traditions. The sheer scale of these volumes means that I can only review a small portion of what they cover. I will first discuss some links of the various contributions in Part I, and then give a list of what can be found in Part II.

It is natural to start with the title and what it conveys. The idea of a 'Cambridge Economics', as encapsulating a people, a place, a way of doing economics and even a field of knowledge is an old one. It is part of the oral tradition in Cambridge and allusions to can be found in book titles (Harcourt (1972)) and in research articles (Marcuzzo et al., 2008). These implicit and explicit references to Cambridge as a place with a special tradition, do not construct the same narratives, nor necessarily share the same intellectual inclusions and exclusions of names and theories in what is the Cambridge tradition in economics. This tradition of creating traditions received recognition with Keynes' rehabilitation of Malthus as "the first of the Cambridge Economists" (Keynes, 1933). His polemical life of Malthus contra Ricardo creates a narrative of different ways of doing economics that is still in contention. This narrative, supported by the winds of change, carried over to The General Theory, and gained wider currency in the profession. How exactly to interpret the narrative of the General Theory remains a topic of disagreement, especially in those traditions in which Keynes' thought still occupies special status.

This disagreement can act as an entry point for a discussion of Part I, and how the different narratives there relate to each other. In the first chapter written by Nuno Martins and titled 'Cambridge Contribution to the Revival of Classical Political Economy', we have a personal synthesis of the various theoretical contributions of the Cambridge Economists and a narrative of how this constitutes a research programme that revives Classical Political Economy. In this chapter Martins argues: "if we interpret the classical theory in line with Sraffa's perspective (which is in line with Marx's original distinction between classical and vulgar theory), we find that Keynes's theory is much more compatible with Ricardo's perspective than with Malthus's, contrary to what Keynes himself 
thought" (p. 17 see also (Martins (2013)). Martins' narrative is interesting as it reverses the inclusion and exclusion of 'Who is a Cambridge Economist?'

John King, in his chapter on 'Post Keynesian Economics in Cambridge' (chapter seven) narrates the history of Post Keynesian economics in Cambridge from the times of Keynes until today. As he discusses the interpersonal relations and theoretical agreements and disagreements of the Cambridge Post Keynesians, he directly asks: "Did Keynes and Sraffa actually agree on fundamentals?" (Italics in original page 143). This remains an open question in Post Keynesian economics, and members of the community suggest different answers, and, also, phrase the question in alternative ways that allows new conceptualisations.

An example of this rephrasing can be found in Sheila Dow's chapter (chapter two) titled 'Cambridge's Contributions to Methodology of Economics' which reviews the complex traditions and approaches in methodology Cambridge economists have worked in. There Dow notes that Martins' (2013) "remarkable study...makes the case (with reference to philosophical foundations) that there has been a revival in Cambridge of the political economy tradition of Smith and Ricardo. Here rather we start with the older political economy tradition in Cambridge, starting with Newton's experimental method, and consider contributions to methodology which could be seen as deviations from this Cambridge tradition as well as the more recent revival of the older methodological tradition"(p. 28). This, Dow notes, constitutes a "third way' approach to methodology." Thus, within three chapters of Part I that directly relate to the Post Keynesian community, we get a number of perspectives on the lineages, nature, form and substance of Post Keynesian economics in Cambridge.

Another way to shape the narrative that answers the question 'what is Cambridge Economics?' is to focus on issues of economic policy. Policy has been a core issue in Cambridge Economics since the very beginning, and this becomes apparent in the chapters on Welfare and Development Economics. Chapter three written by Rogerio Athmar and Michael McLure, focuses on Welfare Economics and traces the tradition of liberalism and practical policy making, touching on issues of redistribution, employment and market failure. This chapter brings more to the fore the work of Pigou and Roberston, weaving a narrative that puts them next to Marshall, Foxwell, Sidgwick, Neville and J.M. Keynes, and without focusing on the strong demarcation lines between 'the Cambridge Welfare Tradition' and the 'Cambridge Keynesian Tradition' that Martins draws in his chapter (p. 19-22).

The chapter on Development Economics (chapter four) is written by Shachi Amdekar and Ajit Singh, and traces the enlightenment roots of Development Economics up to the work of J.M. Keynes and (briefly) his followers. It has an extensive section on Paley and Malthus, "the first of the Cambridge Development Economists" (p. 76), and discusses how Keynes "refers to Malthus's correct line of approach to practical economic problems as compared with Ricardo, and praises the Essay's continuity from the eighteenth- and nineteenth-century classical works on moral philosophy and the human perfectibility debate. Methodologically, Keynesian analysis favoured a return to this Malthusian approach for the purpose of short-term problem solving based on practical, real-world analysis." (Italics in original, page 81)

This naturally brings us to a discussion on data collection and analysis, as it pertains to economic policy, real-world problems, and the context of our current society. What we mean by 'data' depends on the empirical question we have formulated and its context, and for the purposes of this 
review, we can group the chapters on Econometrics, Accounting and Economic History as part of this discussion. Jim Thomas writes the fifth chapter and focuses on advances in econometrics from the 1930 s to the 1960s in Cambridge. This chapter has a brief section on the early history of the Department of Applied Economics, which had Richard Stone as its first Director. The discussion turns to Keynes, the exchanges with Tinbergen on methodology, and how Brian Reddaway changed the direction of the department. And although Reddaway may have had "less interest in econometrics research" (p. 105) than Stone, the Cambridge Growth Project that continued until the late 1980s was one of the largest applied econometrics projects in the UK, and should have received more attention in the chapter.

Chapter nine on Accounting, 'Theories Came and Went, Good Data Endured: Accounting at Cambridge', by Geoff Meeks supplements this history, by adding more detail on the advances in data analysis from an accounting perspective from the time of Colin Clark and Stone until today. Here we get an idea of the various policy contributions Cambridge accountant-economists enacted in national income and business accounting both in UK and internationally. This chapter presents an engaging, inclusive and informative narrative on the link between economic theory and data creation and organisation, and it gives us examples how economic theory as discussed in the other chapters silently instigated real world change.

It may be odd to finish the narrative on this triad of chapters on evidence with Economic History, and yet the chapter written by Martin Daunton - chapter eight, Cambridge and Economic History naturally fits this classification. It starts with the contributions of John Clapham and Michael Postan, who became a formative force for Economic History in the Faculty of History. Postan's thoughts on methodology, which include a belief in situational abstraction, an interest in "precise social and institutional settings" (p. 165) and a preference for "generalizations which are not formulated but merely implied" (Postan, 1968, 63) is, according to Daunton, still a view that most Cambridge economic historians broadly accept. This method made economic historians in Cambridge amass data that ranged from demography and its social structures, to the institutional environment and evolution of different markets and other social institutions. It is worth noting that this interest in institutions is one that the Post Keynesians surveyed in the other chapters also focus on. However, this is not a link the chapter explores at length, showing that there is still room for sustained dialogue between economists and economic historians.

The subject of missing dialogues brings us to the very interesting, if unexpected, chapter on Psychology, which is aptly titled 'Cambridge in the Mind: Economics and Psychology on the Cam' (chapter six) by Vincent Barnett. I enjoy wordplay as much as anyone, and this is a particularly good one- let me explain by digressing. The chapter starts by discussing the origins of Psychology in Cambridge, and especially the work of James Ward, George Stout, and Charles Myers. Between them they cover the period from the last quarter of the $19^{\text {th }}$ century (Ward was born in 1843) to the end of WWII, (Myles died in 1946), and there is clear evidence of social interaction with economists (e.g. the Keynes and Ward families were close (p. 114 also Skideskly 1983, 69)). There is also, as Barnett shows, an affinity in the work of the psychologists, and especially Myles, a near contemporary of Keynes, with Keynes' own policy positions. And yet, there is very little direct evidence of influence or quotation either way. The title of the chapter is an allusion to Sidgwick, who believed there is "such a thing as 'the Cambridge mind'" (p. 111). This again leans on the tradition that the place has certain qualities, derived from strong norms, oral traditions and teachings that predispose those that drink 
water from the river Cam to a certain way of thinking, natural to it, and -to some extent- unique to it.

To return to the wordplay: Whose mind is it that Cambridge inhabits? That of the protagonists', the contributors', the editor's, or the reader's? The statement is somewhat irreverent, but in an elliptical way, it tries to pose two questions. First, what are we to make of the many, different, and occasionally at variance narratives of the Cambridge tradition? Second, what are the limits of this designation, 'Cambridge Economics'?

Before I tackle these questions directly, it is worth noting, briefly, what the reader will find in the second part of the Companion. Space does not allow me to do anything more than list the entries and contributors of the 43 intellectual biographies:

In volume I: William Paley (1743-1805) by A.M.C. Waterman; Robert Malthus (1766-1834) by Samuel Hollander; George Pryme (1781-1868) by Robert Cord; Charles Babbage (1791-1871) by Renee Prendergast; Henry Fawcett (1833-1884) and Henry Sidgwick (1838-1900) by Bart Schultz; Alfred Marshall (1842-1924) by Neil Hart; Herbert Foxwell (1849-1936) by Rogerio Arthmar and Michael McLure; John Neville Keynes (1852-1949) by Rita McWilliams Tullberg; John Clapham (1873-1946) by Martin Daunton, Arthur Pigou (1877-1959) by Karen Knight and Michael McLure, Ralph Hawtrey (1879-1975) by Patrick Deutscher; Frederick Lavington (1881-1927) by Peter Groenewegen.

In volume II: John Maynard Keynes (1883-1946) by D.E. Moggridge; Gerald Shove (1887-1947) by Claudio Sardoni; Dennis Robertson (1890-1963) by Mauro Boianovsky and Charles Goodhart; Austin Robinson (1897-1993) by Geoff Harcourt; Piero Sraffa (1898-1983) by Alessandro Roncaglia; Maurice Dobb (1900-1976) by Hans Despain; Frank Ramsey (1903-1930) by Pedro Duarte; Joan Robinson (1903-1983) by Prue Kerr; Richard Kahn (1905-1989) by Maria Cristina Marcuzzo and Annalisa Rosselli; James Meade (1907-1995) by Susan Howson; Nicholas Kaldor (1908-1986) by John King; David Champernowne (1912-2000) by Mauro Boianovsky; Brian Reddaway (1913-2002) by Ajit Singh; Richard Goodwin (1913-1996) by K. Vela Velupillai; Richard Stone (1913-1991) by Terry Barker; Polly Hill (1914-2005) by Robert Dimand and Kojo Saffu; Phyllis Deane (1918-2012) by Heinrich Bortis; Robin Marris (1924-2012) by Adrian Wood; Frank Hahn (1925-2013) by Robert Solow; Wynne Godley (1926-2010) by Francis Cripps and Marc Lavoie; Robert Matthews (1927-2010) by Geoff Harcourt; Luigi Pasinetti (1930-) by Mauro Baranzini and Pier Luigi Porta; Geoff Harcourt (1931-) by K. Vela Velupillai; Charles Fienstein (1932-2004) by Avner Offer; Amartya Sen (1933-) by Gay Meeks; James Mirrlees (1936-) by Huw Dixon; Robert Rowthorn (1939-) by Paul Ormerod; Ajit Singh (1940-2015) by F.M. Scherer; David Newbery (1943-) by Michael Pollitt, and Antony Atkinson (1944-2017) by Stephen Jenkins.

Any reader will be impressed by the consistently high quality of the contributions. Furthermore, what this part captures well is the sense of community that Cambridge was. It is interesting to see how authors and entries merge together- many are written by colleagues and students of the person whose entry they wrote. There is also continuity across time, as, for example, with Ajit Singh and Geoff Harcourt who contribute an entry and also have an entry. This snapshot of the community, with people speaking about each other's work, is an important contribution as it captures this process at one point in time, concentrating what would, in other cases, be disparate articles by academics writing biographies, reminiscences or notices. It is not only important to capture these 
together, but also to create a venue where this reflection can take place- outside the vagaries of fortune that obituaries are.

Of course, all lists, since the bard's list of ships, are controversial. The controversy has a number angles: length, ordering, inclusions, omissions, coherence and meaning. There isn't space to go into the poetics of lists, but the interested reader may find Spufford (1989) and Eco (2009) useful. I will only list omissions, which may include: Colin Clark (1905-1989), Pierangelo Garegnani (1930-2011), Geoffrey Whittington (1938-), Partha Dasgupta (1942-) and if we extend the terminus date to those born after 1944, Angus Deaton (1945-), Hashem Pesaran (1946-), Kumaraswamy (Vela) Velupillai (1947-) and others.

Which brings me to the subject of missing pieces in the Companion at large. Why isn't there a chapter on the history of the Faculty of Economics, with lists of academic members, notes from important departmental meetings, and possibly lists of the communities of economists in colleges and other departments? Also, why isn't there a chapter directly on the teaching of economics in Cambridge and its evolution from before the organisation of the Economics Tripos until today? These topics have been touched upon indirectly in the contributions. Some work on this has been published elsewhere (Harcourt (2009)). Therefore, these questions mostly pertain to the organisation of the Companion, and this brings me to my main criticism. The introduction is too short and does not explain this project's scope and organisation enough, and the two are not selfevident.

In conclusion, what is Cambridge Economics? My answer is there isn't one tradition, one narrative, one Cambridge Economics. If there is an answer to the question, it is meta-theoretical. It says that there are many ways of doing economics that construct their historical narratives, trace antecedents, form broad pictures of the general stage of economic knowledge, its methodology, and its central questions. An interest in this broad picture (and against too much compartmentalisation of knowledge) I associate with Cambridge. The sustained discussions that some of these contributors have as they refine their theoretical positions and historical narratives is what gives their approach a dynamic element- it never ossifies into one narrative that becomes inviolate. In this mind frame, the effort to try to comprehend the other person's language and see their framework of understanding becomes crucial to the discussion. If this is what Cambridge Economics is, then this multifaceted Companion is an excellent introduction for readers that want to engage with this tradition.

Which leads me to a second question, which is, what are the limits of pluralism? I cannot give a general answer here, but can answer in relation to the Companion. Cambridge is also a place, and the economics practiced there included approaches that are not very well represented in the narratives of the first part. For example, Frank Hahn, James Mirlees and David Newberry all have intellectual biographies, but their work is not discussed in Part I. This tradition of neoclassical economics became, as John King informs us in chapter seven, the dominant force in the Faculty of Economics. It should have had more of a voice in this Companion. It is this wider reach and inclusiveness, achieved by such a diverse set of chapters that distinguishes this Companion from edited volumes that focus only on one approach or tradition.

But these are minor quibbles on a canvas that has already achieved much in capturing Cambridge Economics that they should not distract the reader from the real worth of the Companion. Cord's set will remain as reference work of a people and a place that is central to the discipline and its history. 
References:

Cord, R., 2012, Reinterpreting the Keynesian Revolution, London and New York: Routledge

Eco, U., 2009, The Infinity of Lists: An Illustrated Essay, New York: Rizzoli

Harcourt, G.C., 1972, Some Cambridge Controversies in the Theory of Capital, Cambridge: Cambridge University Press.

Harcourt, G.C., 2009, "100 Years of Economics Tripos". In On Skidelsky's Keynes and Other Essays, 2012, London: Palgrave Macmillan: 327-333

Keynes, J.M., 1933, "Robert Malthus : The First of the Cambridge Economists". In: Essays in Biography, London: Macmillan and Co.: 95-150

Marcuzzo, Maria Cristina, Nerio Naldi, Eleonora Sanfilippo, Annalisa Rosselli, 2008, “Cambridge as a Place in Economics", History of Political Economy, 40 (4): 569-93

Postan, M.M., 1968, "Fact and Relevance in Historical Study", Historical Studies 13(51): 411-425. Reprinted in M.M. Postan (1971) Facts and Relevance: Essays on Historical Method. Cambridge: Cambridge University Press: 48-64.

Skidelsky, R., 1983, John Maynard Keynes: Hopes Betrayed, 1883-1920, London: Macmillan.

Spufford, F., 1989, The Chatto Book of Cabbages and Kings: Lists in Literature, London: Chatto \& Windus. 